\title{
DOM and bacterial growth efficiency in oligotrophic groundwater: absence of priming and co-limitation by organic carbon and phosphorus
}

\author{
Roland Hofmann, Christian Griebler*
}

Institute of Groundwater Ecology, Helmholtz Zentrum München, Ingolstaedter Landstrasse 1, 85764 Neuherberg, Germany

\begin{abstract}
Groundwater ecosystems are low productivity environments due to the small amount and poor quality of organic carbon, and nutrient limitation (N, P). However, field data show the overall presence of degradable DOC. Studies exploring the relationship between carbon properties, nutrient availability and microbial production, as well as possible priming in groundwater are missing. In multi-factorial groundwater batch experiments, we investigated the effect of various organic carbon sources (acetate, organic fertilizer, fulvic acids, humic acids) and nutrients (N, P) to DOC degradation, bacterial production and growth efficiency. Focusing on DOC concentrations, total cell counts, ATP, and bacterial carbon production, our study revealed several important findings. The type of organic carbon offered influenced bacterial growth pattern with lower assimilation efficiencies for the labile but energetically least favorable compound (acetate). Growth on acetate was soon P-limited, while more complex DOM (humic acids) sustained slow but long-term growth. Active but non-growing cells maintained continuous DOC turnover at nutrient limitation. The overall bacterial carbon production and growth efficiency ranged from $<1 \mathrm{ng}$ to $>1 \mu \mathrm{g} \mathrm{C} \mathrm{l^{-1 }}$ $\mathrm{h}^{-1}$ and $<0.1$ to $28 \%$, respectively. None of the experiments revealed evidence for priming in groundwater. This study is a first attempt to unravel the multiple limitations and energetic constraints facing microbial communities in oligotrophic groundwater. Future studies should evaluate these findings by including the sediment matrix which carries the major fraction of microbial biomass and by looking in more detail at the structural characteristics and availability of DOM and P species.
\end{abstract}

KEY WORDS: Bacterial growth - Groundwater - Dissolved organic carbon - Carbon limitation · Nutrient limitation · Priming $\cdot$ Carbon use efficiency $\cdot$ Oligotrophy

\section{INTRODUCTION}

Groundwater (GW) ecosystems in the terrestrial subsurface constitute the largest freshwater biome on earth. Covered by soil layers and sediments of varying dimensions, GW systems are shielded from light, the most important energy source in terms of organic carbon $\left(\mathrm{C}_{\text {org }}\right)$ production. $\mathrm{C}_{\text {org }}$ as well as (specific) nutrients thus mainly derive from the surface and are successively depleted during GW recharge from precipitation, seepage and surface waters (Fredrickson et al. 1989, Frimmel 1992,

${ }^{*}$ Corresponding author: griebler@helmholtz-muenchen.de
Pabich et al. 2001, Lennon \& Pfaff 2005, Shen et al. 2015). Consequently, aquifers are generally poor in energy and low in productivity (oligotrophy) (Goldscheider et al. 2006, Griebler et al. 2014a). Concentrations of dissolved organic carbon (DOC) in oligotrophic GW typically range between 0.2 and $2 \mathrm{mg}$ $1^{-1}$ (Thurman \& Malcolm, 1981), and only a small fraction of the DOC in GW is directly available to and readily degradable by microbes (Gooddy \& Hinsby 2008, Egli 2010, Zhou et al. 2012, Shen et al. 2015). As a consequence, the total number of microorganisms in oligotrophic GW is 10-100 times lower

() The authors 2018. Open Access under Creative Commons by Attribution Licence. Use, distribution and reproduction are unrestricted. Authors and original publication must be credited. 
than in surface waters (Pedersen 2000, Griebler \& Lueders 2009).

Following these observations, there is the general belief that productivity in GW ecosystems, particularly bacterial growth efficiency (BGE) and carbon production (BCP), is mainly limited by bioavailable $\mathrm{C}_{\text {org }}$ (Ford \& Naiman 1989, Jones 1995, Baker et al. 2000). Although plausible, this is contrary to the fact that DOC in GW, even when present at only low concentrations, does always contain some measureable biodegradable (BDOC) and assimilable (AOC) fraction, independent of time, space and age of the GW (Gooddy \& Hinsby 2008, Egli 2010, Zhou et al. 2012, Shen et al. 2015). Taking this into account, the low productivity may also be caused by the simultaneous unavailability of essential (macro)nutrients such as nitrogen or phosphorus (Bengtsson 1989, Egli 1991, Konopka 2000).

Assuming that the DOC present in oligotrophic oxic GW is to a large degree unreactive, often termed recalcitrant or refractory, then the supply of easily degradable $\mathrm{C}_{\text {org }}$ as well as nutrients, providing energy to the microbes, could lead to the stimulation of microbial growth and thereby to a partial transformation of the unreactive $\mathrm{C}_{\text {org }}$. This effect of activation or stimulation of the degradation of previously unreactive organic matter via the addition of extra (labile) $\mathrm{C}_{\text {org }}$ and/or nutrients is called the 'priming effect' (Kuzyakov 2010). While priming effects have been reported from numerous soil studies (Fontaine et al. 2007, Bianchi 2011, Schmidt et al. 2011), its general validity and, in particular, its transferability to aquatic systems is controversial (van Nugteren et al. 2009, Bianchi 2011, Bengtsson et al. 2014, Guenet et al. 2014, Catalán et al. 2015). No study so far has looked for priming in GW.

Microbes that lack nutrients $(\mathrm{N}, \mathrm{P})$ required for new biomass production are, although non-growing, not necessarily non- or minimally active (Konopka 2000). With a surplus of degradable $C_{\text {org }}$, cells increase the ratio of respiration to biomass production (del Giorgio \& Cole 1998). At the same time, fueling the substrate mainly into catabolic metabolism, energy is produced which cannot be dedicated to growth. Apart from possible energy spilling reactions that may then occur, the cells may be expected to be highly active, i.e. in terms of ATP concentration, a fact that has not been addressed so far for GW bacterial communities facing nutrient limitation.

For our study we drafted 4 working hypotheses. (1) Microbial growth in oligotrophic GW is limited by the availability of readily degradable $\mathrm{C}_{\text {org }}$ with the likelihood of a co-limitation by nutrients; (2) Over- coming the carbon and nutrient limitation will not only accelerate bacterial growth but also increase growth efficiency; (3) Supply of labile organic matter and nutrients will 'prime' the degradation of the unreactive DOM pool; (4) Bacteria facing nutrient limitation in GW are non-growing but actively transform organic matter.

Studies tackling the aforementioned issues related to bacterial production and its limitations in oligotrophic GW ecosystems are extremely scarce and mainly descriptive rather than providing clear mechanistic explanations (Baker et al. 2000, Mindl et al. 2000, Longnecker et al. 2009, Foulquier et al. 2011). As a first step towards a more fundamental understanding of bacterial growth efficiency limitations in oligotrophic oxic aquifers, we conducted 2 simple GW batch experiments. In the first (Expt 1), a multiphase run lasting for $371 \mathrm{~d}$, we examined the effect of the amendment of individual types and qualities of DOC or combinations of organic substances on DOC degradation and bacterial growth at ambient nutrient concentrations. DOC sources included (1) acetate (Ac) and $\alpha$-ketoglutarate (KG) as model compounds for easily degradable $\mathrm{C}_{\text {org }}$ (2) fulvic (FA) and humic acids (HA), as typical major components of GW DOC, and (3) the extract of a natural organic fertilizer (OF), containing a mixture of high and low molecular weight humic substances. In a second experiment (Expt 2), lasting for $21 \mathrm{~d}, \mathrm{GW}$ was amended with either HA or Ac as well as with nitrogen and phosphorus to test for possible co-limitations. During the course of the 2 experiments we followed the fate of DOC and nutrient concentrations and monitored the total (prokaryotic) cell counts (TCC) to assess growth. $\mathrm{BCP}$ and BGE were estimated from either ${ }^{3} \mathrm{H}$-leucine incorporation and/or changes in DOC and TCC. In Expt 2, intracellular ATP was followed to evaluate the cell-specific activity status.

\section{MATERIALS AND METHODS}

\section{Experimental design}

The study was organized in 2 separate experiments. The individual treatments, replicates and controls were conducted with natural oligotrophic and oxic GW collected from a shallow unconsolidated quaternary aquifer composed of fluvio-glacial carbonate gravel and sands at Neuherberg/Munich, Germany.

For Phase 1 (Days 0-371) of Expt 1, GW was distributed to ten 21 glass bottles, of which 8 were amended with 4 different $\mathrm{C}_{\text {org }}$ sources (Ac, FA, HA, 
OF) dissolved in GW in duplicates, increasing the initial DOC concentration of $1.5 \pm 0.2 \mathrm{mg} \mathrm{l}^{-1}$ by about $100 \%$. Two bottles did not receive extra DOC and served as controls (Fig. 1). After $71 \mathrm{~d}$ the remaining content ( $>1.51$ ) of each of the ten 21 batches were split into 6 new $250 \mathrm{ml}$ bottles, leading to 60 batch bottles in total. From this day on, the duplicate batches that received no further treatment served as controls of Expt 1-Phase 1. The batches that received 1 individual carbon source were handled as Expt 1Phase 1 and at the same time served as comparison for Expt 1-Phase 2. During Phase 2 (Days 71 to 371), 2 bottles of every experimental subset (Fig. 1) received an extra amount of Ac or KG, respectively, to obtain a total DOC concentration between 7 and $9.5 \mathrm{mg} \mathrm{l}^{-1}$. The DOC concentration of 2 bottles of each subset remained unchanged (Fig. 1).

In Expt 2, lasting for $21 \mathrm{~d}$, GW batch tests (2 l) were amended with $\mathrm{Ac}$, HA or nutrients $(\mathrm{N}+\mathrm{P})$. Addition- ally, batch tests were started with a combination of $\mathrm{Ac}$ or HA and nutrients. One set containing only GW served as control (Fig. 1). Enrichment with $\mathrm{C}_{\text {org }}$ increased the natural DOC background (1.6 \pm $0.15 \mathrm{mg} \mathrm{l}^{-1}$ ) by a factor of 2.5. Addition of the nutrient mixture $\left(\mathrm{NaNO}_{3}\right.$ and $\left.\mathrm{NaH}_{2} \mathrm{PO}_{4}\right)$ resulted in an increase in $\mathrm{NO}_{3}-\mathrm{N}$ from originally $1.3 \pm 0.01$ to $3.5 \pm$ $0.03 \mathrm{mg} \mathrm{l}^{-1}$ (from 6 to $16 \mathrm{mg} \mathrm{l}^{-1} \mathrm{NO}_{3}^{-}$) and in $\mathrm{PO}_{4}-\mathrm{P}$ from $16 \pm 0.15 \mathrm{\mu g} \mathrm{l}^{-1}$ to $25 \pm 2.2 \mathrm{\mu g} \mathrm{l}^{-1}$ (from 48 to $75 \mathrm{\mu g} \mathrm{l}^{-1} \mathrm{PO}_{4}{ }^{3-}$ ).

All batch experiments were conducted at $12^{\circ} \mathrm{C}$ in the dark with bottles placed on a shaker at $90 \mathrm{rpm}$ to avoid oxygen depletion. The bottles were loosely sealed with aluminium foil to prevent contamination. Individual bottles were regularly sub-sampled to follow changes in DOC and nutrient concentrations, to monitor biomass production of prokaryotic cells (hereafter 'bacteria') as well as occasionally cellular ATP concentrations.

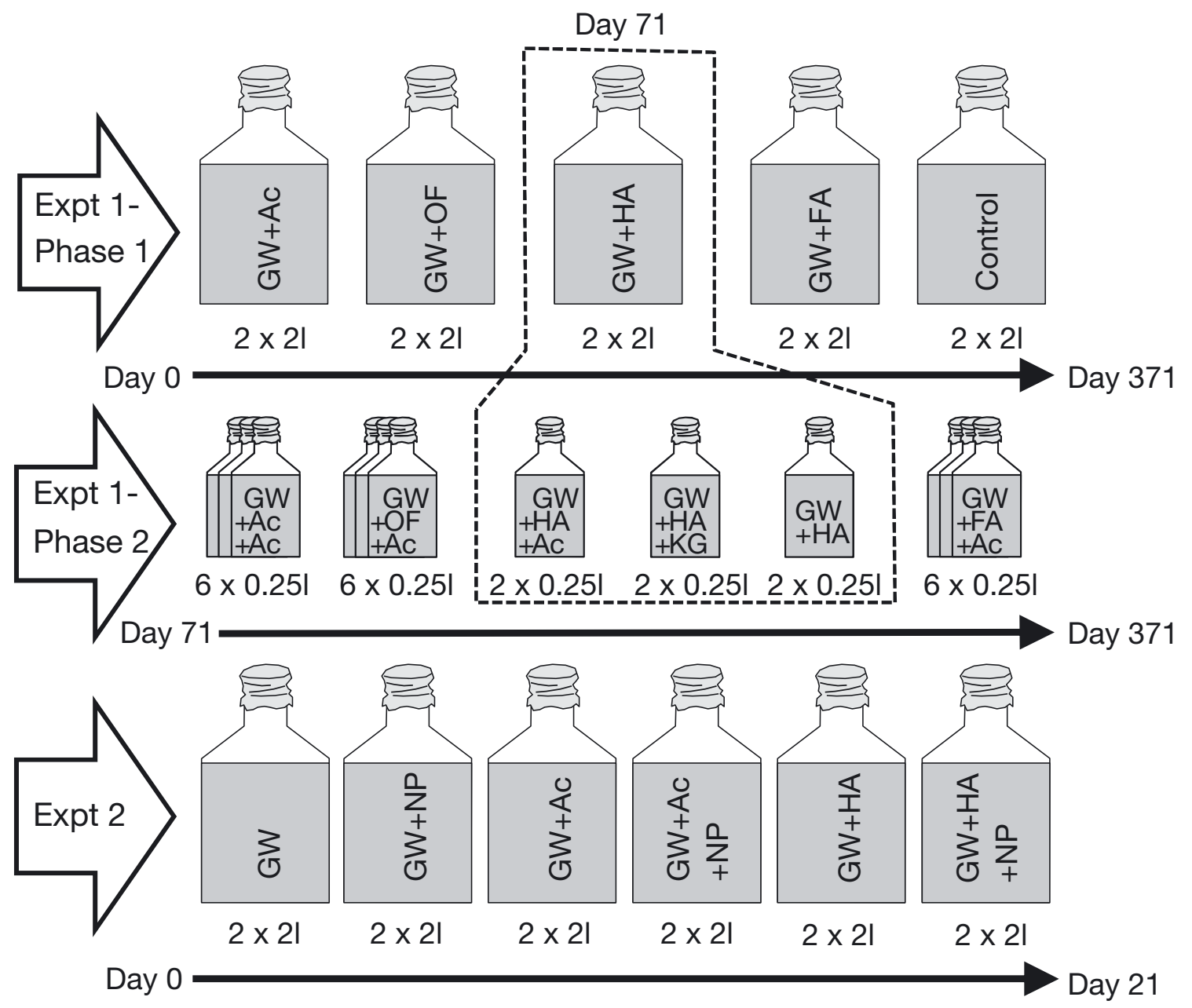

Fig. 1. Set-up of the 2 batch experiments. GW: groundwater; FA: fulvic acids; HA: humic acids; Ac: acetate; OF: organic fertilizer; NP: nutrients (nitrogen + phosphorus) 


\section{Carbon sources}

HA and FA were extracted from deep GW collected from borehole Gohy-573 at Gorleben (Lower Saxony, Germany). Details on isolation and composition are provided by Wolf et al. (2004). OF is, according to the manufacturer's information, mainly composed of humic substances of varying molecular size (PhytoGreen ${ }^{\circledR}$-HumusWP; PhytoSolution). Stock solutions were prepared by dissolving the lyophilized substrates at a $\mathrm{pH}$ of 9 in ultrapure water, followed by neutralization. Sodium acetate (Ac; Sigma Aldrich) was dissolved in ultrapure water. All solutions were sterile-filtered $\left(0.22 \mu \mathrm{m}_{i}\right.$ Millipore) and stored at $4^{\circ} \mathrm{C}$ in darkness before use.

\section{DOC and nutrient analyses}

For DOC measurements, 5-10 $\mathrm{ml}$ of GW were subsampled, then filtered through a $0.45 \mu \mathrm{m}$ syringe filter (Millipore), before acidification with $2 \mathrm{M} \mathrm{HCl}$ to $\mathrm{pH}<2$. Before use, the filters were rinsed with $\geq 20 \mathrm{ml}$ of ultrapure lab water to reduce contamination from leaching $\mathrm{C}_{\text {org }}$. The non-purgeable $\mathrm{C}_{\text {org }}$ was analysed in a TOC analyser (Shimadzu TOC-5000A).

For the analyses of nutrients $\left(\mathrm{NO}_{3}{ }^{-}, \mathrm{NO}_{2}{ }^{-}, \mathrm{NH}_{4}{ }^{+}\right.$, $\mathrm{PO}_{4}{ }^{3-}$ ) and major ions, $200 \mu \mathrm{l}$ of GW were filtered through a $0.1 \mu \mathrm{m}$ pre-rinsed syringe filter (Millipore) in triplicates and analysed in a Dionex ICS-1100 ion chromatograph (Thermo Fisher Scientific). For elution of cations $2.2 \mathrm{mM} \mathrm{H}_{2} \mathrm{SO}_{4}$ (IonPac CS12A, $4 \mathrm{~mm}$ column; Dionex) and for anions, a mixture of $1.7 \mathrm{mM}$ of $\mathrm{NaHCO}_{2} / 1.8 \mathrm{mM} \mathrm{Na}_{2} \mathrm{CO}_{3}$ buffer (IonPac AS4ASC, $4 \mathrm{~mm}$ column; Dionex) was used. The Chromelion software (Thermo Fisher Scientific) was used for data analysis. The limit of detection (LOD) for the ion chromatography (IC) measurements was defined as $0.1 \mathrm{mg} \mathrm{l}^{-1}$.

Since orthophosphate measurements in Expt 1 by means of IC were not sensitive enough, in Expt 2 a more sensitive spectrophotometric assay based on the phosphomolybdic acid methodology (Murphy \& Riley 1962) was applied. Here, all soluble inorganic and organic $\mathrm{P}$ is digested to orthophosphate and, per definition, the soluble reactive phosphorus (SRP) is determined (EN ISO 6878). The LOD was determined as 3 times the standard deviation of blank determinations and was calculated as $10 \mu \mathrm{g} \mathrm{PO}_{4}{ }^{3-} \mathrm{l}^{-1}$ $\left(3.3 \mu \mathrm{g} \mathrm{PO}_{4}-\mathrm{P} \mathrm{l}^{-1}\right)$. Since natural phosphate concentrations were very low and only inorganic phosphate was added, values from IC (orthophosphate) and colorimetric (SRP) analysis were both handled as orthophosphate.

\section{ATP and total cell counts}

Water samples were analyzed for intracellular ATP following the protocol provided by Hammes et al. (2010).

TCC were determined after fixation of $1 \mathrm{ml}$ of triplicate GW samples with glutardialdehyde $(2.5 \% \mathrm{v} / \mathrm{v}$, final conc.). Counting of SybrGreen stained cells was performed via flow cytometry (FC-500, Beckman Coulter) following the protocol described in Bayer et al. (2016).

\section{Bacterial growth rates and carbon use efficiency}

BCP was occasionally estimated via incorporation of tritium labelled leucine $\left(\left[4,5{ }^{3} \mathrm{H}\right]\right.$ L-leucine; Hartmann Analytics) into bacterial proteins adopting the protocol given in Brielmann et al. (2009). Triplicate samples of $50 \mathrm{ml}$ and a control, which was fixed immediately after ${ }^{3} \mathrm{H}$-leucine addition $(10 \mathrm{nM}, 44 \mathrm{Ci}$ $\mathrm{mmol}^{-1}$ ), were incubated for $8 \mathrm{~h}$ at $12^{\circ} \mathrm{C}$ in the dark. For precipitation of proteins, formaldehyde-fixed liquid samples (3.7\% final conc.) were incubated with ice-cold trichloroacetic acid (TCA, 10\% v/v). After collection of macromolecules on a $0.2 \mu \mathrm{m}$ cellulose nitrate filter (Millipore), dried filters were dissolved in ethyl acetate. After addition of scintillation cocktail, samples were stored overnight at $4^{\circ} \mathrm{C}$ before measurement in a liquid scintillation counter. Carbon production ( $\mu \mathrm{g} \mathrm{C}^{-1} \mathrm{~h}^{-1}$ ) was calculated as described in Kirchmann (1993).

Bacterial growth rates $(\mu)$ were calculated as quotient of $\ln \left(x / x_{0}\right)$ and $\Delta$ time, and generation times $(g)$ were calculated as $g=\ln 2 / k=0.693 / k$. Carbon consumption (degradation) rates $(k)$ were determined as first-order kinetics. Maximum rates were estimated for the periods with the steepest slope; mean rates for over the entire test period.

BGE was calculated in 2 ways: (1) according to the function provided in del Giorgio \& Cole (1998); and (2) via an indirect calculation from the net bacterial biomass produced in the batch tests and the amount of DOC degraded. The $\mathrm{C}_{\text {org }}$ content of prokaryotic cells applied for calculations, was estimated by measuring length and width of at least 100 cells of each batch under an epifluorescence microscope (Axiovision; Zeiss), followed by the calculation of cell carbon contents as described in Wilhartitz et al. (2009). A 
mean $\mathrm{C}_{\text {org }}$ content of $46 \mathrm{fg} \mathrm{C} \mathrm{cell}^{-1}$ was assumed for the HA, FA, and OF treatments, and a carbon content of $124 \mathrm{fg} \mathrm{C}_{\mathrm{Cell}}^{-1}$ for the Ac treatments. For the GW control, a cell carbon content of $20 \mathrm{fg} \mathrm{C}$ was applied (Griebler et al. 2002).

\section{Statistics}

Statistical analyses were performed using 2-sided $t$-test for 2 independent samples. Analyses of developments along a timeline were performed using a 1 -way ANOVA with repeated measurements. For direct comparison of DOC degradation and bacterial growth, the time series were analysed by a linear regression analysis or, in case of non-linearity, by Spearman rank correlation. p-values $<0.05$ were considered as significant.

\section{RESULTS}

The freshly collected oxic and oligotrophic GW for Expt 1 was characterized by a DOC concentration of $1.5 \pm 0.2 \mathrm{mg} \mathrm{l}^{-1}$. The concentration of $\mathrm{NO}_{3}-\mathrm{N}$ was $1.5 \pm 0.15 \mathrm{mg} \mathrm{l}^{-1}$. Nitrite $\left(\mathrm{NO}_{2}^{-}\right)$and ammonium $\left(\mathrm{NH}_{4}^{+}\right)$were below the LOD of $0.1 \mathrm{mg} \mathrm{l}^{-1}$. In Expt 1, when phosphate was followed by only ion chromatography, it was always below the LOD $\left(100 \mathrm{\mu g} \mathrm{l}^{-1}\right.$ for $\mathrm{PO}_{4}{ }^{3-}$ ). Reconstructing a $\mathrm{PO}_{4}-\mathrm{P}$ value from earlier analyses and measurements conducted in Expt 2 with the same GW revealed a $\mathrm{PO}_{4}-\mathrm{P}$ value of about $15 \mu \mathrm{g} \mathrm{l^{-1 }}$. The oligotrophic GW contained $1.9 \times 10^{4} \pm$ $2.2 \times 10^{3} \mathrm{ml}^{-1}$ bacterial cells. The bacterial carbon production (BCP) in untreated GW, as estimated via ${ }^{3} \mathrm{H}$-leucine incorporation, ranged from 1.3 to $77 \mathrm{ng} \mathrm{C}$ $\mathrm{l}^{-1} \mathrm{~h}^{-1}$.

\section{Expt 1-Phase 1 (Days 0-371)}

The extra $\mathrm{C}_{\text {org }}$ added to oligotrophic GW resulted in an increase of $60 \%$ (Ac treatment) to $195 \%$ (OF treatment) of the DOC pool in the batch tests (Fig. 2). One to $3 \mathrm{~d}$ after the $\mathrm{C}_{\text {org }}$ supply, a decline in DOC started to occur in the different treatments. Within $14 \mathrm{~d}$, the DOC concentrations dropped by $81 \%$ from the maximum values in the treatment with $\mathrm{OF}, 46 \%$ with Ac, $26 \%$ with HA and 17\% with FA (Fig. 2). While the FA and OF incubations then revealed stagnation in DOC levels for the following $232 \mathrm{~d}$ or even to the end of Expt 1 (OF, Day 371), DOC in the Ac treatment continued declining until Day 42 before it leveled off. The HA treatment exhibited a declining trend until Day 112 (Fig. 2). Spearman rank analysis revealed a strong correlation between the DOC decrease in the treatment and control $(r=0.65)$ for the FA and Ac batches, respectively. When excluding the Day 14 DOC value (outlier) for the untreated GW (control), a fast decline in DOC of $40 \%$ (Days 0-7) was observed followed by stagnation for the remaining period of Expt 1. A priming effect, i.e. the drop of DOC concentration in bottles amended with extra $\mathrm{C}_{\text {org }}$ below the lowest DOC concentration reached in the controls (untreated GW) was observed with the Ac incubation only. A comparison of the DOC degradation with control for each treatment revealed no significant differences $(p>0.05$; Table 1$)$. The final period (Days 246-371) of Expt 1-Phase 1 was characterized by some further decline in DOC concentrations with all treatments (Fig. 2).

Bacterial growth in the different treatments followed the onset of DOC consumption with a delay of 2-5 d. In particular, bottles treated with OF showed an extended lag-phase in growth until Day 7. In the first 2 wk of incubation TCC increased 20 -fold in the Ac, 17 -fold in the HA, 5-fold in the FA, and 4-fold in the OF treatments, and almost doubled in the controls (Fig. 2). However, only the Ac incubations revealed a very early (Days 7-14) but intermediate peak in TCC. In the batches with OF, HA and FA, cell numbers, after an initial fast increase, continued rising until Day 91, albeit at a lower growth rate, peaking in TCC several weeks later than the Ac incubation (Fig. 2). The initially fast growth rates of the individual experiments with extra $\mathrm{C}_{\text {org }}$ differed significantly from the control $(\mathrm{p} \leq 0.05$; Table 1$)$ and with different $\mathrm{C}_{\text {org }}$ sources. With the exception of the FA treatments, similar maximum cell numbers were reached in the Ac, OF and HA batches. In all cases (except the control), the period of pronounced growth was followed by a transient decline in TCC. Moreover, in parallel to the DOC patterns, the first phase of fast bacterial growth was followed by no growth (OF, HA) or comparably low growth (Ac, FA, control) between Days 91 and 371 (Fig. 2).

Occasional monitoring of the nitrate concentration revealed a minimum of approx. $0.4 \mathrm{mg} \mathrm{l}^{-1} \mathrm{NO}_{3}-\mathrm{N}$ in the different batch tests at the end of Expt 1-Phase 1 (data not shown). $\mathrm{PO}_{4}-\mathrm{P}$ was at about $15 \mu \mathrm{g} \mathrm{l} \mathrm{l}^{-1}$ at the beginning of Expt 1 (see data for natural GW with Expt 2). However, since the IC assessment applied in Expt 1 was not sensitive enough, as already stated in the 'Materials and methods', $\mathrm{PO}_{4}-\mathrm{P}$ values are not available for the course of Expt 1 and possible P limitations could not be evaluated. 


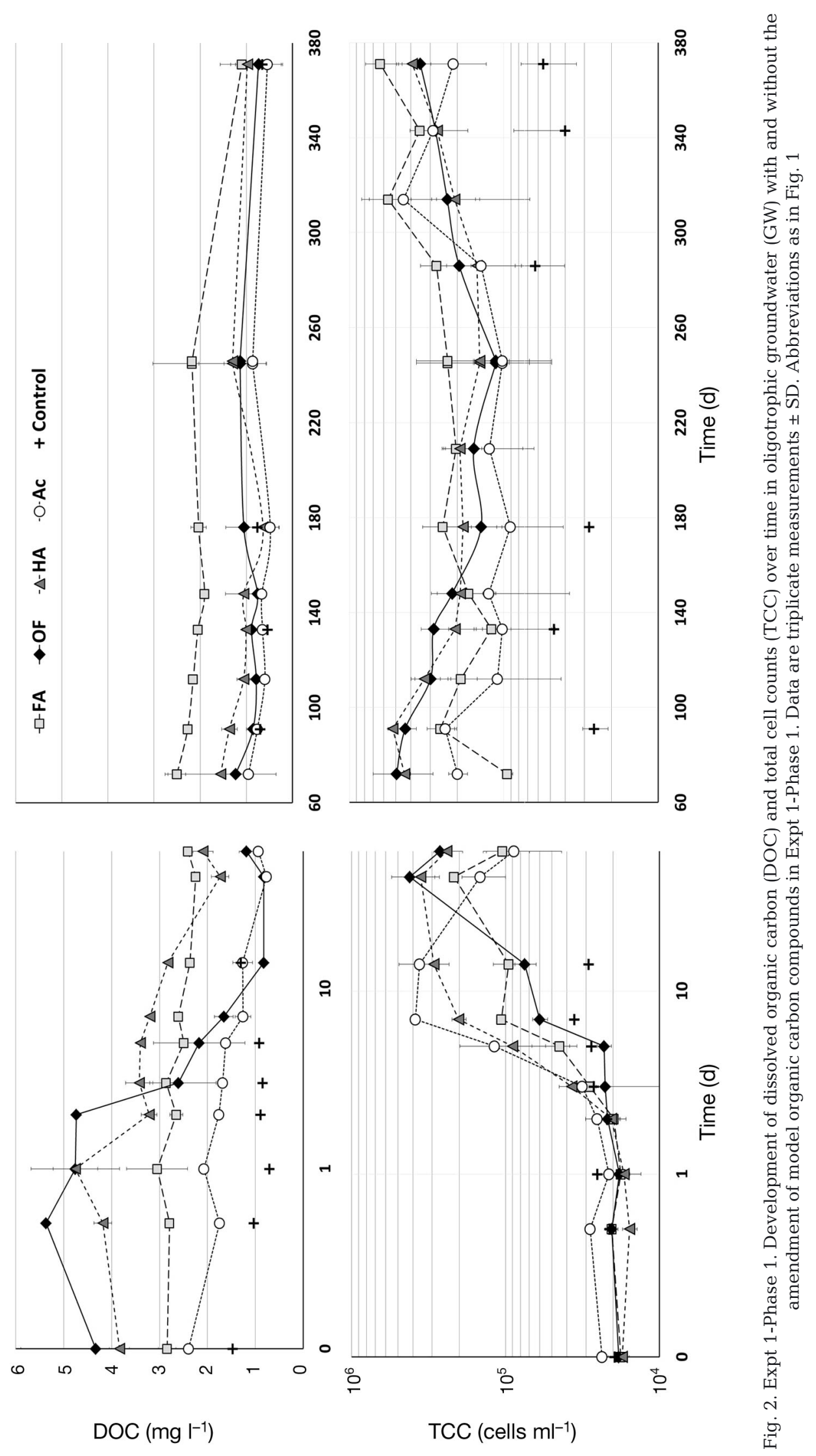


Table 1. Growth rates $(\mu)$ and DOC degradation rates $(k)$ in the different treatments of Expt 1-Phase 1 and Expt 1-Phase 2 (abbreviations as in Fig. 1). Where possible, a $t$-test for independent samples was applied to compare with the control batches. Data are means $( \pm S D)$. Values in bold indicate significant differences to controls $(p<0.05)$

\begin{tabular}{|c|c|c|c|c|c|c|}
\hline \multirow[t]{3}{*}{ Treatment } & \multicolumn{2}{|c|}{ Expt 1-Phase $1-$} & \multirow{2}{*}{\multicolumn{4}{|c|}{ 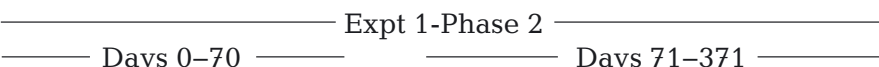 }} \\
\hline & \multirow{2}{*}{$\begin{array}{l}k_{\max } \\
\left(\mathrm{d}^{-1}\right)\end{array}$} & \multirow{2}{*}{$\begin{array}{l}\mu_{\max } \\
\left(d^{-1}\right)\end{array}$} & & & & \\
\hline & & & $k_{\max }\left(\mathrm{d}^{-1}\right)$ & $\mu_{\max }\left(\mathrm{d}^{-1}\right)$ & $k\left(\mathrm{~d}^{-1}\right)$ & $\mu\left(d^{-1}\right)$ \\
\hline FA & -0.074 & 0.337 & -0.070 & 0.017 & $-0.017 \pm 0.002$ & $0.006 \pm 0.001$ \\
\hline OF & -0.337 & 0.480 & -0.031 & 0.008 & $-0.019 \pm 0.001$ & $0.005 \pm 0.004$ \\
\hline $\mathrm{HA}$ & -0.151 & 0.457 & -0.065 & 0.018 & $-0.021 \pm 0.004$ & $0.002 \pm 0.001$ \\
\hline $\mathrm{Ac}$ & -0.165 & 0.624 & -0.023 & 0.007 & $-0.015 \pm 0.001$ & $0.005 \pm 0.001$ \\
\hline Control & -0.025 & 0.028 & - & - & $-0.001 \pm 0.001$ & $0.002 \pm 0.002$ \\
\hline
\end{tabular}

\section{Expt 1-Phase 2 (Days 71-371)}

At Day 71 of Expt 1, batches were split and partially re-supplied with Ac or KG (now Expt 1-Phase 2) while untreated tests continued (Expt 1-Phase 1) (Fig. 1). The addition of Ac was followed by pronounced declines in DOC in the treatments that had not received Ac earlier. However, it took until Day 260 for $40-70 \%$ of the newly supplied Ac to be degraded in the batches that originally received OF $(66 \%)$, HA $(42 \%)$ and FA (50\%). The bottles that received Ac twice, exhibited a slower decline in DOC, with only $30 \%$ of the newly supplied Ac consumed in $100 \mathrm{~d}$ (Fig. 3).
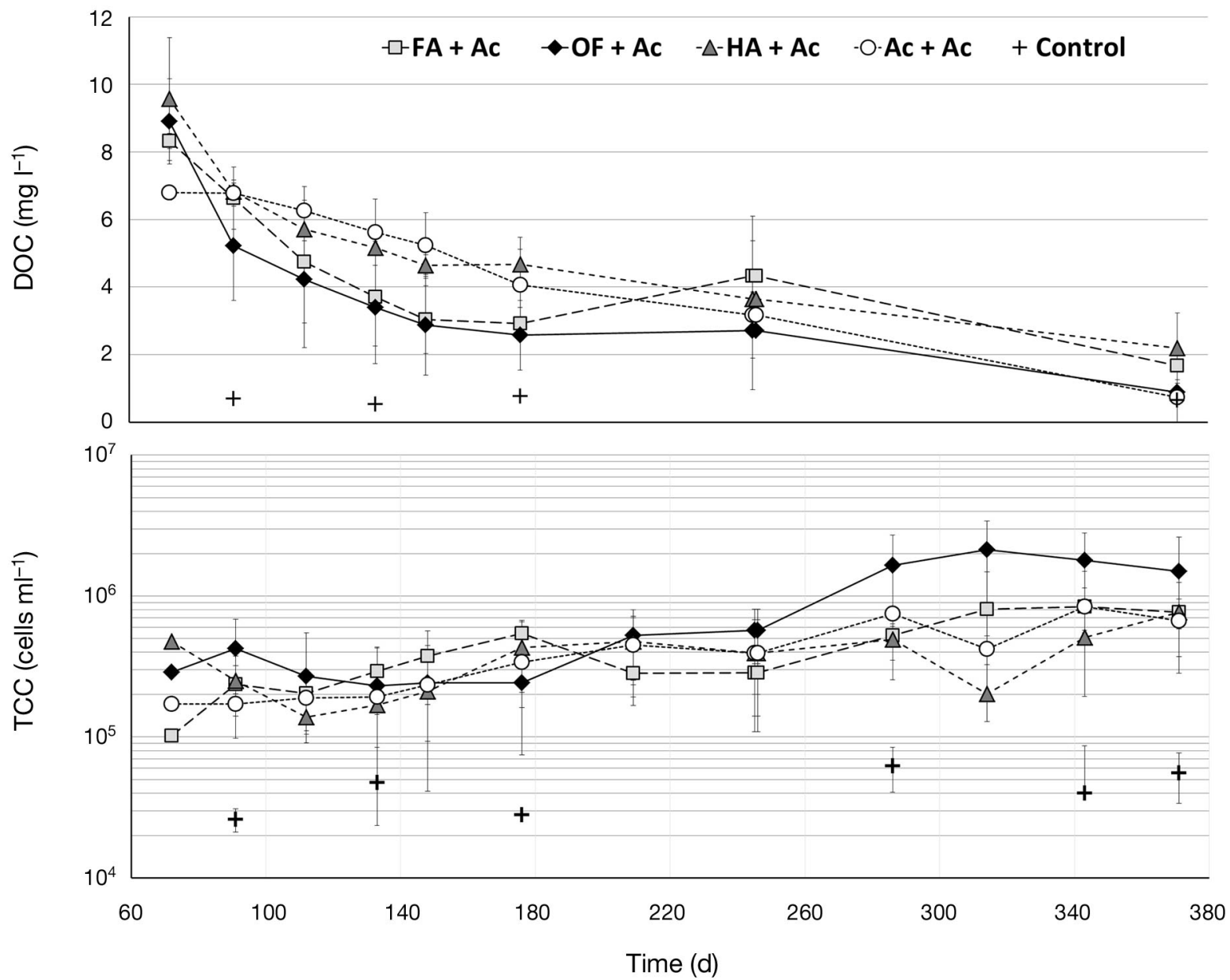

Fig. 3. Expt 1-Phase 2. Development of DOC and TCC over time (Days 72-371) in groundwater (GW) that first received individual organic carbon sources at Day 0 and were supplied with acetate at Day 71. Data are triplicate measurements \pm SD.

Abbreviations as in Figs. $1 \& 2$ 
The mean DOC removal rate of all treatments, with the exception of the Ac+Ac amendment was $-0.025 \pm$ $0.0018 d^{-1}$ (Days 71-371). Samples amended with Ac twice showed a $17 \%$ lower DOC degradation rate. However, at the end of the incubation (Day 371) all batch tests had DOC concentrations comparable to the treatments of Expt 1-Phase 1. In detail, the $\mathrm{HA}+\mathrm{Ac}$ and $\mathrm{FA}+\mathrm{Ac}$ bottles still contained $1.28 \pm$ $0.37 \mathrm{mg} \mathrm{l}^{-1}$ more DOC than the controls. The Ac+Ac and $\mathrm{OF}+\mathrm{Ac}$ batches contained an equal amount or slightly lower concentration of DOC than the controls (Figs. 2 \& 3). One-way ANOVA for DOC values at the end of Expt 1 revealed a significant difference between the treatments re-supplied with Ac and those without $(\mathrm{p}<0.05)$.

Although substantial amounts of labile $\mathrm{C}_{\text {org }}$ were added, the TCC did not change in accordance to the DOC patterns. In contrast, the entire Expt 1-Phase 2 was characterized by a slow linear growth in a comparable range for all different incubations (Table 1). Only OF+Ac revealed a pronounced increase in TCC towards the end of the experiment (Days 245-371). At the end of Expt 1, TCC in the batches having received a second OC supply (Expt 1-Phase 2) were slightly higher than in the treatments with $\mathrm{C}_{\text {org }}$ supplied only once (Expt 1-Phase 1) (Figs. 2 \& 3). Compared with the controls, this difference was significant ( $\mathrm{p} \leq 0.05)$ only for the OF+Ac and HA+Ac batches.

In the batches that were amended with KG instead of $A c$, patterns were very similar (data not shown). Only in one subset that received FA+KG, the TCC increased by more than one order of magnitude within the first 2 wk after KG supply. Later, these high TCC started to decrease again, until they reached the level of all the other incubations at Day 314.

The concentrations of nitrogen in the batches of Expt 1-Phase 2 were in similar range (0.10-0.13 mg $\mathrm{N}-\mathrm{NO}_{3} \mathrm{l}^{-1}$ ) to those in bottles of Expt 1-Phase 1 at the end of the incubation (Day 371), implying that no direct $\mathrm{N}$ limitation had occurred.

\section{Bacterial carbon production and growth efficiency}

To estimate the BGE the $\triangle \mathrm{TCC}$ and $\triangle \mathrm{DOC}$ were evaluated between Days 0 and 371 for Expt 1Phase 1 as well as between Days 71 and 371 for Expt 1-Phase 2. Moreover, direct measurements of BCP were conducted on Days 0, 3, 7 and 14 during Phase 1 of Expt 1 (Table 2).

Direct measurements of BCP revealed a significant increase after the addition of $\mathrm{C}_{\text {org }}$. The Ac-supplied batches unfortunately lack direct BCP measurements for Days 7 and 14. The highest BCP was observed for

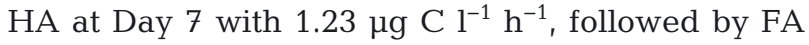

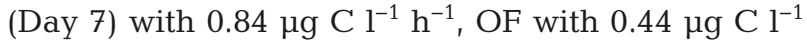
$\mathrm{h}^{-1}$, and Ac with $0.21 \mu \mathrm{g} \mathrm{C} \mathrm{l}^{-1} \mathrm{~h}^{-1}$. Using the function given by del Giorgio \& Cole (1998) these values convert into BGEs of $28 \%$ (HA, Day 7), $22 \%$ (FA, Day 7), $15 \%$ (OF, Day 14), and $9 \%$ (Ac, Day 3), respectively. Control samples, as already mentioned above, ranged in BCP between 1.3 and $77 \mathrm{ng} \mathrm{Cl}^{-1} \mathrm{~h}^{-1}$, translating into $23 \%$ and $46 \%$ of the carbon fixed in new bacterial biomass (Table 2).

BGEs calculated from $\triangle \mathrm{TCC}$ and $\triangle \mathrm{DOC}$ for the short period of pronounced bacterial growth in

Table 2. Bacterial growth efficiency (BGE) throughout Expt 1 and Expt 2. BGE values originate either from direct bacterial carbon production measurement via ${ }^{3} \mathrm{H}$-leucine incorporation (meas.) or calculation from $\Delta \mathrm{TCC}$ and $\triangle \mathrm{DOC}$ (calc.). (+/-AC) indicates whether batch incubations received a re-supply with acetate in Expt 1-Phase 2 or were left unamended, respectively. $(+/-N P)$ indicates whether bottles received an extra supply of nitrogen and phosphorus, or were left unamended, respectively. nd: not done. Other abbreviations as in Fig. 1

\begin{tabular}{|c|c|c|c|c|c|c|c|}
\hline \multirow{2}{*}{ Experiment } & \multirow{2}{*}{ Time } & \multirow{2}{*}{ Origin of results } & \multicolumn{5}{|c|}{ - BGE by treatment (\%) } \\
\hline & & & FA & OF & HA & $\mathrm{Ac}$ & GW \\
\hline \multirow{4}{*}{ Expt 1-Phase 1} & Day 0 & meas. & 2.3 & 2.2 & 2.5 & 2.5 & 2.3 \\
\hline & Day 3 & meas. & 5.4 & 4.7 & 16 & 8.5 & 3.4 \\
\hline & Day 7 & meas. & 22.1 & 13.3 & 27.6 & nd & 3.4 \\
\hline & Day 14 & meas. & 10.8 & 14.5 & 23.8 & nd & 4.6 \\
\hline \multirow[t]{2}{*}{ Expt 1-Phase 1} & Days 0-371 & calc. & 3.1 & 3.5 & 3.0 & 3.7 & 0.8 \\
\hline & Days 7-14 & calc. & 1.6 & 0.6 & 0.6 & 3.9 & 0.06 \\
\hline Expt 1-Phase 2 (-Ac) & Days 71-371 & calc. & 3.9 & 3.6 & 3.7 & 6.1 & 2.5 \\
\hline Expt 1-Phase 2 (+Ac) & Days 71-371 & calc. & 2.5 & 3.4 & 2.3 & 4.0 & 2.0 \\
\hline Expt $2(-\mathrm{NP})$ & Days 0-21 & calc. & & & 8.4 & 1.9 & 1.2 \\
\hline Expt $2(+N P)$ & Days $0-21$ & calc. & & & 9.2 & 4.8 & 1.3 \\
\hline
\end{tabular}


Phase 1 (Days 7-14) revealed much lower values. Here, highest BGE was obtained for the Ac incubation with $3.9 \%$, followed by the FA $(1.6 \%)$, the HA and OF (both $0.6 \%$ ), and the control batches $(<0.1 \%)$ (Table 2). The BGE for the entire Expt 1-Phase 1 resulted in similar values for all $\mathrm{C}_{\text {org }}$ amended incubations, with $3.0-3.7 \%$. The control samples again were lowest with only $0.8 \%$ of the carbon consumed turned into biomass carbon.

During Expt 1-Phase 2 all incubations that did not receive additional Ac stayed at the same level, with BGEs between 3.6 and $3.9 \%$ for OF, HA, FA. Only the Ac batches had a higher mean value of $6.1 \%$. The control samples had the lowest BGE of $2.5 \%$. In fact, the additional supply of Ac to all initial $\mathrm{C}_{\text {org }}$ treatments led to a decrease of the BGE (Table 2).

\section{Expt 2: short-term incubation}

The incubation of oxic oligotrophic GW in Expt 2 with or without extra nutrients $(\mathrm{N}, \mathrm{P})$ caused a decrease in DOC by $30 \%$ (not significantly different from Day $0 ; \mathrm{p}>0.05$ ) and $50 \%$ (significantly different from Day $0 ; \mathrm{p}<0.05)$, respectively, after $21 \mathrm{~d}$. The TCC increased slightly, but not significantly from $1.6 \times 10^{4}$ to $5.2 \times 10^{4} \mathrm{ml}^{-1}$ (3.2 times, $\left.\mathrm{p}>0.05\right)$ in unamended GW and $4.3 \times 10^{4} \mathrm{ml}^{-1}(2.7$ times, $\mathrm{p}>0.05)$ in GW supplied with nutrients. Strikingly, the prokaryotic cells in GW, although hardly multiplying, exhibited a continuously increasing ATP/TCC ratio. In GW with extra nutrients the ATP/TCC ratio increased slightly at the beginning, but highest values were reached with a delay of 2 wk (Fig. 4).

The addition of Ac to GW was followed by a total mineralization of the extra $\mathrm{C}_{\text {org }}$ within the $21 \mathrm{~d}$. However, development of TCC between GW and GW+AC over time was not significantly different ( $p>0.05)$. In fact, although almost 5 times more DOC was consumed, only twice as many cells were produced. However, the amendment of extra nutrients (GW+ $\mathrm{Ac}+\mathrm{NP})$ strikingly speeded up DOC consumption, this time paralleled by a pronounced cell growth. After only $1 \mathrm{wk}$, all of the readily degradable DOC was gone and cell numbers increased by 3 orders of magnitude (Fig. 4). While the ATP/TCC ratio increased over time in the GW+Ac batches that lacked pronounced growth, it remained low in the GW+ Ac+NP treatments, after a short initial peak (Fig. 4).

Finally, the addition of HA to GW exhibited a pattern in between the GW and the GW+Ac experiments. Independent of nutrient supply, only 1.6$1.7 \mathrm{mg} \mathrm{ml}^{-1}$ of DOC was degraded. If we account for the $0.5 \mathrm{mg} \mathrm{ml}^{-1}$ from the GW itself, only about $1 \mathrm{mg}$ $\mathrm{ml}^{-1}$ of HA was consumed in $21 \mathrm{~d}$. The DOC decrease in the HA batches was mirrored by a continuous increase in TCC. After $21 \mathrm{~d}$, TCC increased 60- to 70 -fold (Fig. 4). The ATP/TCC ratio in the HA treatment remained low throughout the experiment. As can be easily seen from the DOC data in Fig. 4, Expt 2 did not provide any evidence for priming.

Linear regression analysis revealed significant correlation with respect to DOC $(\mathrm{r}=0.51$ [GW] to 0.89 $[\mathrm{GW}+\mathrm{Ac}] ; \mathrm{p}<0.05)$ and TCC $(\mathrm{r}=0.39[\mathrm{GW}+\mathrm{NP}]$ to $\left.0.83[\mathrm{GW}+\mathrm{HA}]_{i} \mathrm{p}<0.05\right)$ for all curves, with the exception of TCC in the GW+AC+NP treatment $(\mathrm{r}=$ $0.02 ; \mathrm{p}=0.36$ ). There was in all cases an overlap of the confidence intervals between the parallel treatments (with or without NP).

\section{Nutrient limitation in Expt 2}

From the data on nitrogen species (only nitrate was detected) at Days 0 and 21 it is obvious that no nitrogen limitation occurred during Expt 2 (Fig. 4). The picture is different for phosphorus. In all incubations the $\mathrm{P}$ level dropped significantly $(\mathrm{p}<0.05)$, indicating that $\mathrm{P}$ was a limiting factor for bacterial growth. Where extra nutrients were added, P concentrations declined to even lower values (Fig. 4). Final concentrations of $\mathrm{PO}_{4}$-P were below the general LOD $(3.3 \mu \mathrm{g}$ $\mathrm{l}^{-1}$ ) in the range of $1 \mu \mathrm{g} \mathrm{l}^{-1}$, as revealed by manual peak integration following UPEC guidelines (>3 SD).

\section{Bacterial growth efficiency in Expt 2}

BGEs calculated for Expt 2 (Days 0-21) revealed lowest values in the untreated control incubations (GW) and the nutrient-amended groundwater (GW+ NP). BGEs ranged between $1.2 \%$ and $1.3 \%$ (Table 2). Highest BGEs were obtained for the HA batches, with $8.4 \%$ without and $9.2 \%$ with NP, respectively. In contrast, the Ac treatments exhibited a clear difference in BGE with and without the NP addition (Table 2).

\section{DISCUSSION}

Our study revealed 4 important findings. First, prokaryotic productivity in oxic oligotrophic GW was limited by the availability of biodegradable organic carbon; however, a co-limitation by $\mathrm{P}$ occurred in several cases. Second, the type (redox state), compo- 

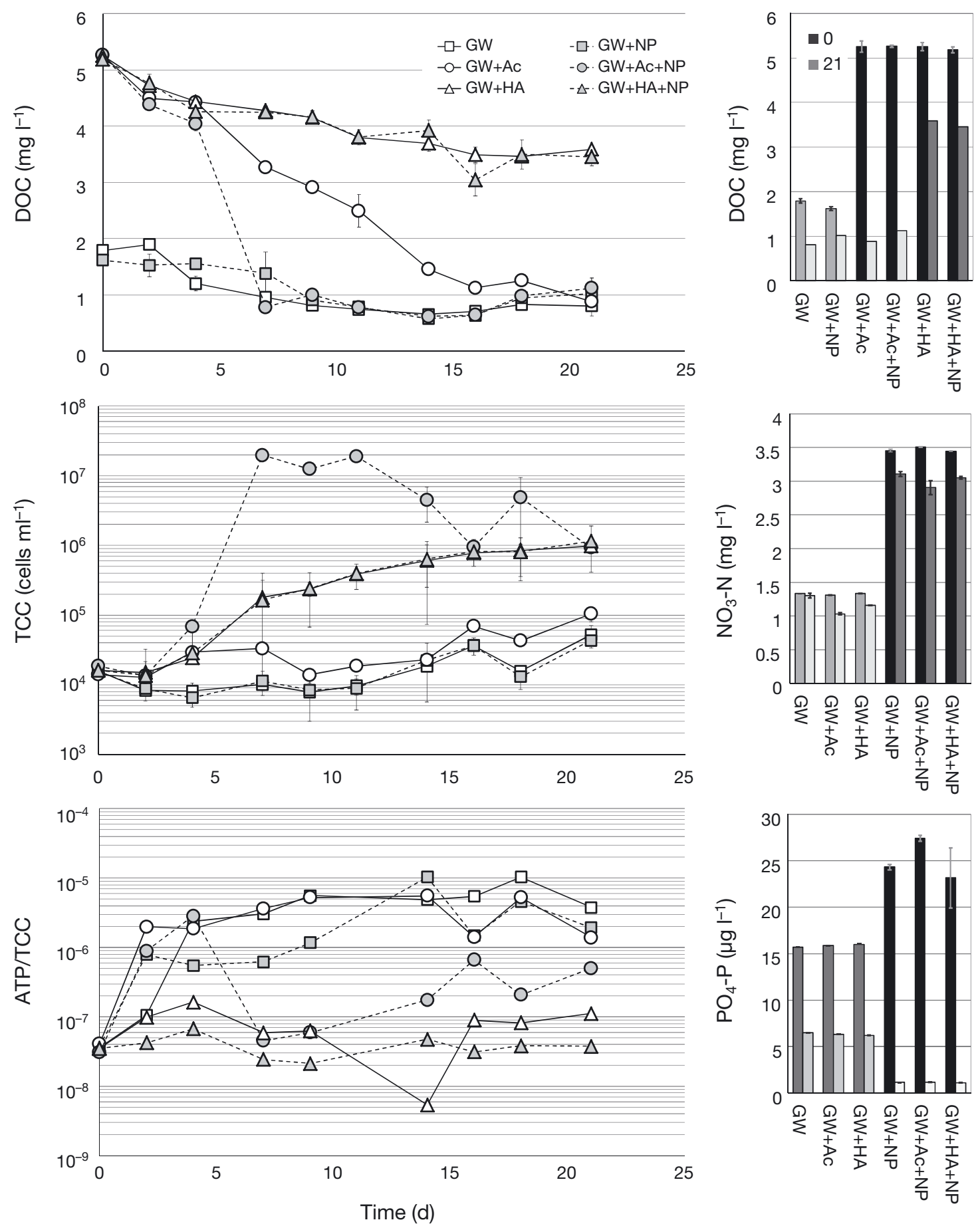

Fig. 4. Development of DOC, TCC and ATP/TCC after incubation of groundwater with acetate (Ac), humic acids (HA), and/or nutrients (NP). In half of the samples (dashed lines) a possible nutrient limitation was eliminated by the addition of $\mathrm{NO}_{3}$ and $\mathrm{PO}_{4}$. Charts to the right show the $\mathrm{DOC}, \mathrm{NO}_{3}-\mathrm{N}$, and $\mathrm{PO}_{4}-\mathrm{P}$ concentrations for the different incubations at Days 0 (darker bars) and 21 (lighter bars)

sition (nutrient content) and quality (degradability) of the organic matter played a crucial role with respect to degradation kinetics and BGE. Third, the addition of readily available carbon to GW did not reveal a priming effect, i.e. the stimulated transformation of unreactive DOC. Finally, with degradable organic carbon available but lacking nutrients, active but non-growing cells continuously respired $\mathrm{C}_{\text {org }}$ and 
were characterized by a high intracellular ATP content, indicating bacterial adaptations to nutrient limitation. These findings are briefly discussed in light of the existing knowledge.

\section{GW ecosystems are energetically constrained}

Covered by soil and sediment layers of varying dimensions, GW ecosystems are well protected from surface related impacts. From the 'down below' perspective, aquifers and their inhabitants (mainly prokaryotes) are shielded from important energy sources, i.e. $\mathrm{C}_{\text {org }}$ and nutrients, originating from surface terrestrial and aquatic environments (Griebler et al. 2014a). During their passage to the aquifer, $\mathrm{C}_{\text {org }}$ in seepage water and surface water recharging aquifers is significantly reduced in concentration and changed in degradability (Fredrickson et al. 1989, Frimmel 1992, Kalbitz et al. 2000, Pabich et al. 2001, Shen et al. 2015). Moreover, along with the mineralization of $\mathrm{C}_{\text {org }}$ and abiotic adsorption and complexation reactions, the recharge water is also sequentially depleted in specific nutrients (e.g. P) (Pretty et al. 2006). In consequence, oxic aquifers hold GW that is typically poor in $\mathrm{C}_{\text {org }}$ and phosphorus and are oligotrophic (low productivity). This characteristic is mirrored in the comparable low abundance of prokaryotic cells (bacteria), 10 to 100 times lower than in oligotrophic surface waters, and a lower fraction of highly active cells (Kieft \& Phelps 1997, Griebler \& Lueders 2009). In other words, the main fraction of bacterial cells is expected to be small in size, and of low activity (low ATP content) or even dormant. In fact, this is the picture drawn from the available literature.

\section{Evidence for $\mathbf{C}_{\text {org }}$ limitation}

Microbial productivity in GW ecosystems is generally considered to be limited by $\mathrm{C}_{\text {org }}$ with respect to concentration, flux and biodegradability (Ford \& Naiman 1989, Jones 1995, Malard \& Hervant 1999, Baker et al. 2000). However, there are a few aspects worth considering. First, GW sampled from any point and depth within an aquifer always contains some BDOC or AOC, typically in the range 1-100 $\mathrm{\mu g} \mathrm{l}^{-1}$ (Bradford et al. 1994, Escobar \& Randall 2001, Gooddy \& Hinsby 2008, Egli 2010, Zhou et al. 2012, Shen et al. 2015). Assuming that a bacterial cell in GW has a carbon content of about $20 \mathrm{fg}$ (Griebler et al. 2002, Wilhartitz et al. 2009) and there are $1 \times 10^{7}$

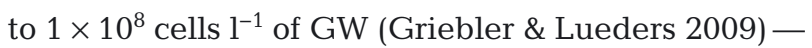
resulting in $0.2-2 \mu \mathrm{g}$ biomass carbon $\mathrm{l}^{-1}$-then $>10 \mu \mathrm{g} \mathrm{l}^{-1}$ of BDOC should allow doubling of the cell biomass, assuming a mean BGE of about $25 \%$ as reported for aquatic environments (del Giorgio \& Cole 1998).

Our 2 batch experiments showed that within the first $1-3 \mathrm{wk}$ of incubation, $40-50 \%$ of the ambient DOC (1.5-1.6 $\left.\mathrm{mg} \mathrm{l}^{-1}\right)$ in untreated oligotrophic oxic GW was biodegraded. A BDOC content of $40-50 \%$ is at the upper range reported for GW (Baker et al. 2000, Mindl et al. 2000, Mermillod-Blondin et al. 2015, Shen et al. 2015 and references therein). In Expt 1-Phase 1 only $1.61 \times 10^{7}$ new cells were produced, accounting for approximately $0.32 \mu \mathrm{g} \mathrm{C}$ of $600 \mu \mathrm{g}$ DOC degraded. The bacterial abundance increased by a factor of 1.8. In Expt 2, the $800 \mu \mathrm{g}$ DOC degraded yielded $3.64 \times 10^{7}$ new cells $(0.73 \mu \mathrm{g}$ C), i.e. a 3.3-fold increase in cell abundance. Thus, by calculation via the $\triangle \mathrm{DOC}$ and $\triangle \mathrm{TCC}$, only $0.05-0.1 \%$ of the DOC degraded was fixed in newly produced biomass. The GW and its microbial communities tested in our experiments had among the lowest carbon use efficiency values reported for aquatic ecosystems (del Giorgio \& Cole 1998, Eiler et al. 2003 and references therein).

While we could not assess P limitation in Expt 1, Expt 2 clearly showed that the addition of $\mathrm{PO}_{4}{ }^{3-}$ to oligotrophic GW did not lead to a significantly higher productivity (Table $2 ; \mathrm{p}>0.05$ ), indicating C-limitation. However, it may not only be the biodegradability of the DOC in oligotrophic GW that matters but also its low total concentration as was shown for deep sea habitats (Arrieta et al. 2015), leading to slow microbial growth in oligotrophic GW. As highlighted below, although $\mathrm{C}$-limited, the addition of $\mathrm{C}_{\text {org }}$ led, in some cases, to nutrient limitation.

\section{Evidence for nutrient limitation}

According to Liebig's law of the minimum, overcoming the major limitation of one substrate leads to limitation by another. However, in nature, and with microbial communities, simultaneous limitation by more than one substrate/element is very likely (Paerl 1977, Egli 1991, Teixeira de Mattos \& Neijssel 1997, Konopka 2000). Numerous experiments and studies targeting microbes in aquatic environments revealed a stronger response to the amendment of combined resources ( $\mathrm{C}$ and $\mathrm{N}$ or $\mathrm{P}$ ) than with individual sources, indicating a co-limitation (Dorado-García et al. 2014 and references therein). 
Besides $\mathrm{C}_{\text {org }}$, the availability of essential nutrients such as $\mathrm{N}$ and $\mathrm{P}$ may limit microbial growth and production (Egli 1991, Konopka 2000). It is striking that in Expt 1-Phase 1, independent from the total amount of $\mathrm{C}_{\text {org }}$ amended to the oligotrophic $\mathrm{GW}$, a similar cell abundance was reached in all incubations (Fig. 2), indicating a certain carrying capacity that could be limited by nutrients. Moreover, Ac is a relatively oxidized compound that yields comparably little energy, strongly indicating that a factor other than $\mathrm{C}_{\text {org }}$ is limiting bacterial productivity.

Since, nitrogen values did not fall below $0.4 \mathrm{mg} \mathrm{l}^{-1}$ $\mathrm{NO}_{3}-\mathrm{N}\left(=1.8 \mathrm{mg} \mathrm{l}^{-1} \mathrm{NO}_{3}{ }^{-}\right.$), N-limitation seemed unlikely. $\mathrm{C}: \mathrm{N}$ ratios of 9.5 and 3.8 have been reported for bacterioplankton biomass growing under nutrientlimited to non-limited conditions, respectively (Vrede et al. 2002). Taylor \& Townsend (2010) give an average inflection point of 3.5 (range from 2.2 to 5.2) for the DOC: $\mathrm{NO}_{3}$ ratio. Only at higher ratios, which rarely occurred in our experiments, does N-limitation become likely. Moreover, since shallow GW is commonly impacted by nitrogen from fertilizer used in intensive agriculture (e.g. Stoewer et al. 2015), N-limitation in shallow oxic GW will rarely take place. The switch from an $\mathrm{N}$ to a $\mathrm{P}$ limitation is suggested at N:P ratios of <3-16 (Keck \& Lepori 2012 and references therein). Limitation by phosphorus is thus more likely in shallow oxic GW (Miettinen et al. 1997).

In oxic conditions, $\mathrm{PO}_{4}{ }^{3-}$ tends to adsorb to and react/complex with metals (e.g. Fe) and with humic substances. Therefore, although the application of fertilizers also releases some amounts of $\mathrm{P}$ to land surface and soils, concentrations of $\mathrm{PO}_{4}{ }^{3-}$ and other SRP species in GW are generally low (Bengtsson 1989, Brielmann et al. 2009). Unfortunately our analytic approach (IC) applied in Expt 1 was not sensitive enough to follow $\mathrm{PO}_{4}{ }^{3-}$ concentrations appropriately. However, what we learned from the analyses conducted in Expt 2 is that $\mathrm{PO}_{4}-\mathrm{P}$ values in the GW used ranged from 10-15 $\mu \mathrm{g} \mathrm{l}^{-1}$. From a solely stoichiometric perspective of bacterial biomass - characterized by a C:N:P ratio of about 50:10:1 (Goldman et al. 1987, Vrede et al. 2002) - these amounts of $P$ should be sufficient to generate $10^{10}$ to $10^{11}$ new cells. However, at low P concentrations, capture and microbial uptake (flux into the cell) of $\mathrm{P}$ may be insufficient to cover growth requirements (Konopka 2000). Besides the structural composition of the cell, $\mathrm{P}$ is mainly needed for catabolism (Hessen \& Anderson 2008), see 'Non-growing but highly active cells' below.

In Expt 2, where we specifically investigated nutrient limitation, our results were puzzling. In the batches with $\mathrm{Ac}$, the additional amendment of $\mathrm{N}$ and $\mathrm{P}$ induced pronounced bacterial growth. Nutrient analysis clearly revealed that $\mathrm{P}$ was the limiting factor (Fig. 4). However, in the batches with HA that received extra nutrients, $\mathrm{C}_{\text {org }}$ degradation was accompanied by considerable cell growth, which was similar to that in bottles without NP amendment. Moreover, in the batches with extra nutrients added, the P concentration was significantly lower after $21 \mathrm{~d}$ (Fig. 4).

As mentioned earlier, $\mathrm{PO}_{4}{ }^{3-}$ is very reactive and tends to react with humic substances. Indeed, HAs consist of a highly complex mixture of molecules with different organic side groups, metal ions and bound nitrogen and phosphorus (Hertkorn et al. 2002). We may thus expect that the HA used contained some $P$ and $\mathrm{N}$, which were released during degradation and subsequently supported bacterial growth. Additionally, the extra phosphate added to the HA batches may have reacted with the humic substances indicated by the low phosphate values at the end of incubation. In conclusion, humic substances provide some essential nutrients that allow considerable growth, which is controlled by a combination of the degradability of the HAs and the flux of nutrients in the HAs to and into the cells (Konopka 2000).

P-limitation of microbial growth was shown in several studies conducted with surface waters (Smith \& Prairie 2004, Thingstad et al. 2005, Keck \& Lepori 2012 and references therein); however, similar studies in ground and drinking water are scarce (Bengtsson 1989, Miettinen et al. 1997).

\section{No evidence for priming}

The effect of priming refers to the activation or stimulation of degradation of previously unreactive organic matter via the addition of extra (labile) $\mathrm{C}_{\text {org }}$ and or nutrients (Kuzyakov 2010). Although the underlying mechanisms are still enigmatic and under intensive discussion, the effect itself is well supported from soil studies (Bianchi 2011, Schmidt et al. 2011). For aquatic systems, there is only little information reporting controversial evidence (van Nugteren et al. 2009, Bianchi 2012, Bengtsson et al. 2014, Guenet et al. 2014, Catalán et al. 2015). Guenet et al. (2010) gathered some experimental results and field observations that strongly support the hypothesis that the priming effect is a general phenomenon that occurs in terrestrial, freshwater, and marine ecosystems. This study is the first to address possible priming effects in oligotrophic GW. However, inde- 
pendent of the amount and quality of $\mathrm{C}_{\text {org }}$ supplied and the co-amendment of essential nutrients, no evidence of a priming effect could be observed in our study. In fact, the DOC concentration did not drop below that of the controls in any of the treatments receiving $\mathrm{C}_{\text {org }}$ or nutrients. Similar results were obtained by Catalán et al. (2015), who assessed potential priming effects in waters from lakes of different trophic states. Bengtsson et al. (2014), focusing on headwater stream biofilms, did not observe changes in respiration, removal or incorporation of allochthonous organic matter in response to autochthonous treatments, again not supporting a priming effect under experimental conditions. One reason for the absence of priming in oligotrophic GW may be the already low concentration of $\mathrm{C}_{\text {org }}$, i.e. $1.5-1.6 \mathrm{mg}$ $\mathrm{l}^{-1}$. It should be noted, however, that in our incubations, the natural oligotrophic GW - when transferred to the glass bottles and incubated over weeks to months in the dark at ambient temperature $\left(12^{\circ} \mathrm{C}\right)$ - exhibited a loss in DOC of $30-50 \%$. This is a large loss considering that the DOC in GW is assumed to be rather recalcitrant and slow-degradable. There is obviously a bottle-effect, known from comparable studies (Fuhrman \& Bell 1985), which is similar to a priming-effect.

\section{Bacterial growth efficiency}

Only part of the $\mathrm{C}_{\text {org }}$ oxidized and consumed by bacterial communities is converted to new biomass. The variability in bacterial carbon use or growth efficiency is related to the concentration, flux and quality of the substrate, as well as to the availability of essential nutrients, frequently leading to an uncoupling between rates of production and respiration (Teixeira de Mattos \& Neijssel 1997, Carlson et al. 2007, del Giorgio \& Newell 2012). Values of BGE in different aquatic environments typically range from 5 to $50 \%$ (del Giorgio \& Cole 1998, Manzoni et al. 2012). However, there are a few studies that show considerably lower BGEs (del Giorgio \& Cole 1998, del Giorgio \& Newell 2012). Data for oligotrophic GW and aquifers are scarce, although Griebler et al. (2014b) determined BGE values ranging from 2 to $20 \%$ (mean of $6 \%$ ) in GW from more than 100 sites in Germany. The GWs tested thus fall at the lower end of the BGE range among aquatic habitats reported (del Giorgio \& Cole 1998, Eiler et al. 2003 and references therein). This low productivity in groundwater is generally considered to be due to the low total amount of $\mathrm{C}_{\text {org }}$ and the small pool of labile organic matter (Griebler \& Lueders 2009, Griebler et al. 2014a). In our batch experiments, we assessed how the addition of $\mathrm{C}_{\text {org }}$ with variable content in labile DOC as well as the (co)amendment of nitrogen and phosphorus affects the BGE.

The addition of FA to GW stimulated fast bacterial growth for a period of $5 \mathrm{~d}$ before reaching a plateau. The supply of HA stimulated bacterial growth for $12 \mathrm{~d}$, and OF for up to $37 \mathrm{~d}$. Ac showed the fastest reaction in terms of bacterial growth, however, after $1 \mathrm{wk}$, cell numbers again declined to a lower level.

The direct measurements of BCP performed for the early experimental phase of growth (Days 0-14) in Expt 1-Phase 1, revealed the highest BGE of almost $28 \%$ with the HA incubations, followed by GW that received FA (22\%), and OF (15\%). Supplied with Ac, the GW bacterial community showed a BGE of $9 \%$, only twice as high as GW not receiving extra DOC (5\%; Table 2). Unfortunately, measurements of Days 7 and 14 were missing for this Ac treatment. BGEs calculated from changes in cell numbers and DOC, revealed a different picture. Here, GW communities receiving Ac exhibited a BGE of $4 \%$ while all other incubations had values $<2 \%$. In the nonamended GW only $0.8 \%$ of the DOC consumed was converted into biomass. Such low values have been observed so far only in the most dilute, oligotrophic systems (del Giorgio \& Cole 1998). In Expt 1-Phase 2, again the Ac incubations produced slightly higher BGE values $(4-6 \%)$ than the incubations with other $\mathrm{C}_{\text {org }}$ sources. It is worth mentioning that in Expt 1Phase 2 the addition of labile DOC (Ac) to all initial $\mathrm{C}_{\text {org }}$ treatments led to an overall 3-fold decrease of BGE (Table 2). Since calculations of BGEs for Expt 1Phase 1 and Phase 2 integrated much longer time periods, compared to Expt 2, we assume that reamendment of DOC and P-limitation shaped the overall pattern together with the influences from $\mathrm{C}_{\text {org }}$ concentration and quality.

In Expt 2, the HA-supplied GW bacterial community were characterized by BGEs of 8 and $9 \%$ without and with extra nutrients, respectively. As already mentioned above, in the HA incubations the amendment of nutrients did not change the overall growth patterns. Differently in the AC incubations, overcoming the P-limitation the BGE increased from 2 to $5 \%$ (Table 2).

The picture obtained by the few direct measurements of $\mathrm{BCP}$ is supported by thermodynamics. In fact, the most readily biodegradable but most oxidized $\mathrm{C}_{\text {org }}$ source $(\mathrm{Ac})$ provides the least energy and therefore the lowest BGE (del Giorgio \& Cole 1998). Moreover, since the direct measurements were con- 
ducted only in the early phase of Expt 1, a limitation by $\mathrm{P}$ might not have been fully developed. A similar pattern is observed from Expt 2, where BGEs were estimated from cell counts and DOC turnover, and degradation of HA supported higher BGE than living on Ac. However, the BGE values derived from the direct measurements of $\mathrm{BCP}$ need to be treated with caution, since BCP measurement via incorporation of radiolabel leucine or thymidine during lab incubation was repeatedly discussed to overestimate in situ activities (e.g. Phelps et al. 1994), and the formula provided by del Giorgio \& Cole (1998) for the conversion of BCP to BGE may not fit well for BCP values at the lower range.

At low substrate concentrations, $\mathrm{C}_{\text {org }}$ is primarily used in catabolic reactions providing energy to the cell but resulting in low BGE (Stouthamer \& Bettenhausser 1973, Russell \& Cook 1995). The energy is spent for the production of extracellular enzymes and cell wall transporter proteins to increase the flux of substrate and nutrients into the cell (Middelboe \& Sondergaard 1993, Button 1994, del Giorgio \& Cole 1998, Konopka 2000). Several studies underlined a positive relationship between DOC and $\mathrm{BGE}$; however, it holds true for only very oligotrophic environments with DOC concentrations of a few milligrams per liter and less (Eiler et al. 2003 and references therein). Similarly, lower substrate quality (recalcitrant or more oxidized) will cause low BGEs (Vallino et al. 1996, Hertkorn et al. 2002, Eiler et al. 2003, Nebbioso \& Piccolo 2013). Finally, the limitation of bacterial growth by one or more nutrients shifts the ratio of bacterial production vs. respiration towards respiration, lowering growth efficiency.

In summary, BGEs in GW bacteria were at the lower range of known values, i.e. $<0.1-4.6 \%$. Overcoming the carbon and nutrient limitation increased BGE $(0.6-28 \%)$ to values similar to those reported for oligrotrophic surface aquatic environments (del Giorgio \& Cole 1998, Eiler et al. 2003 and references therein). A possible bias in our estimations of $\mathrm{BCP}$ could be protozoan grazing and cell lysis due to bacteriophages. However, in our opinion these microbial food web interactions, highly important in surface waters, are of less influence in oligotrophic GW. While protozoan grazing may play a significant role in organically contaminated GW (Kinner et al. 2002), protozoan densities are generally very low in oligotrophic GW (Novarino et al. 1997). However, most solid evidence comes from our flow cytometric cell counts that rarely revealed cells $>3 \mu \mathrm{m}$ in size. Finally. occasional microscopic evaluations indicated numbers of possible grazers to be several orders of magnitude lower (data not shown). Similarly, the comparable low probability of phages to meet a suitable host is decreased by orders of magnitude in GW caused by the much lower numbers of phages and bacteria (Cram et al. 2016), and active bacteria in particular. Nevertheless, our calculations of BGE ignored possible grazing and phage effects, an assumption that needs to be validated in future work.

\section{Non-growing but highly active cells}

As already highlighted above, cells facing a limitation are forced to uncouple their catabolism from anabolism (Carlson et al. 2007). Exposed to a surplus in substrate but lacking essential nutrients for biomass production, $\mathrm{C}_{\text {org }}$ is funnelled almost exclusively to catabolic reactions gaining energy (Hessen \& Anderson 2008). We thus hypothesized that cells provided with DOC but lacking $\mathrm{N}$ and/or $\mathrm{P}$ have a higher specific activity and in consequence a higher internal ATP level. And indeed, there is some evidence from the results obtained in Expt 2. Cells in oligotrophic GW (control) as well as in the Ac incubations lacking phosphorus revealed higher ATP values than their counterparts incubated under nonlimiting conditions (GW+Ac+NP) (Fig. 4). A variability of intracellular ATP in relation to carbon and nutrient limitation has been reported earlier by Wilson et al. (1981) and Pridmore et al. (1984). What is not clear is how the cells lacking $P$ are able to sustain a high ATP level over time. This will be focus of future studies.

\section{Water vs. sediment microbial communities}

Finally, it is important to mention that in GW ecosystems the majority of microbes are associated with mineral surfaces (Alfreider et al. 1997, Griebler et al. 2002). Moreover, attached microbes have better access to organic carbon and nutrients, which consequently leads to higher cell-specific activities (Griebler et al. 2014a). Last but not least, although microbes freely suspended in GW and those attached to the sediment surfaces share a considerable core community (e.g. Zhou et al. 2012, Flynn et al. 2013), a large fraction of microbes in aquifers are found exclusively in GW, and thus are suggested to act as a travelling seed bank (Griebler et al. 2014a). Our study on growth dynamics of GW bacterial communities is only a first step and experiments as well as field studies including sediment-associated microorganisms 
are urgently needed. Also, the effect of grazers and phages awaits further consideration.

Acknowledgements. This study was funded by the German Research Foundation (DFG) under the grant GR 2107/3-1 to C.G., as well as by the Helmholtz Water Center Munich within the Helmholtz Research Platform for the Integrated Assessment of Solute Fluxes and Processes in the Regional Water Cycle. This contribution was further funded by the Helmholtz Research Program Terrestrial Environment (Topic 3 - Sustainable Water Resource Management). Thanks go to B. Michalke and colleagues from the Research Unit Analytical BioGeoChemistry at HMGU for help with the nutrient analyses. Comments of 2 anonymous reviewers substantially improved the manuscript.

\section{LITERATURE CITED}

Alfreider A, Krössbacher M, Psenner R (1997) Groundwater samples do not reflect bacterial densities and activity in subsurface systems. Water Res 31:832-840

Arrieta JM, Mayol E, Hansman RL, Herndl GJ, Dittmar T, Duarte CM (2015) Dilution limits dissolved organic carbon utilization in the deep ocean. Science 348:331-333

Baker MA, Valett HM, Dahm CN (2000) Organic carbon supply and metabolism in a shallow groundwater ecosystem. Ecology 81:3133-3148

Bayer A, Drexel R, Weber N, Griebler C (2016) Quantification of aquatic sediment prokaryotes - a multiple-steps optimization testing sands from pristine and contaminated aquifers. Limnologica 56:6-13

Bengtsson G (1989) Growth and metabolic flexibility in groundwater bacteria. Microb Ecol 18:235-248

* Bengtsson MM, Wagner K, Burns NR, Herberg ER, Wanek W, Kaplan LA, Battin TJ (2014) No evidence of aquatic priming effects in hyporheic zone microcosms. Sci Rep 4: 5187

Bianchi TS (2011) The role of terrestrially derived organic carbon in the coastal ocean. A changing paradigm and the priming effect. Proc Natl Acad Sci USA 108: 19473-19481

Bradford SM, Palmer CJ, Olson BH (1994) Assimilable organic carbon concentrations in Southern California surface and groundwater. Water Res 28:427-435

* Brielmann H, Griebler C, Schmidt SI, Michel R, Lueders T (2009) Effects of thermal energy discharge on shallow groundwater ecosystems. FEMS Microbiol Ecol 68: 273-286

Button DK (1994) The physical base of marine bacterial ecology. Microb Ecol 28:273-285

Carlson CA, del Giorgio PA, Herndl GJ (2007) Microbes and the dissipation of energy and respiration: from cells to ecosystems. Oceanography 20:89-100

* Catalán N, Kellerman AM, Peter H, Carmona F, Tranvik LJ (2015) Absence of a priming effect on dissolved organic carbon degradation in lake water. Limnol Oceanogr 60: 159-168

Cram JA, Parada AE, Fuhrman JA (2016) Dilution reveals how viral lysis and grazing shape microbial communities. Limnol Oceanogr 61:889-905

del Giorgio PA, Cole JJ (1998) Bacterial growth efficiency in natural aquatic systems. Annu Rev Ecol Syst 29:503-541

del Giorgio PA, Newell REI (2012) Phosphorus and DOC availability influence the partitioning between bacterio- plankton production and respiration in tidal marsh ecosystems. Environ Microbiol 14:1296-1307

* Dorado-García I, Medina-Sánchez JM, Herrera G, Cabrerizo MJ, Carrillo P (2014) Quantification of carbon and phosphorus co-limitation in bacterioplankton: new insights on an old topic. PLOS ONE 9:e99288

Egli T (1991) On multiple-nutrient-limited growth of microorganisms, with special reference to dual limitation by carbon and nitrogen substrates. Ant Leeuwenhoek 60: $225-234$

Egli T (2010) How to live at very low substrate concentration. Water Res 44:4826-4837

*Eiler A, Langenheder S, Bertilsson S, Tranvik LJ (2003) Heterotrophic bacterial growth efficiency and community structure at different natural organic carbon concentrations. Appl Environ Microbiol 69:3701-3709

* Escobar IC, Randall AA (2001) Assimilable organic carbon (AOC) and biodegradable dissolved organic carbon (BDOC): complementary measurement. Water Res 35: 4444-4454

Flynn TM, Sanford RA, Ryu H, Bethke CM, Levine AD, Ashbolt NJ, Domingo JWS (2013) Functional microbial diversity explains groundwater chemistry in a pristine aquifer. BMC Microbiol 13:146

Fontaine S, Barot S, Barre P, Bdioui N, Mary B, Rumpel C (2007) Stability of organic carbon in deep soil layers controlled by fresh carbon supply. Nature 450:277-280

*FFord TE, Naiman RJ (1989) Groundwater-surface water relationships in boreal forest watersheds. Dissolved organic carbon and inorganic nutrient dynamics. Can J Fish Aquat Sci 46:41-49

*Foulquier A, Mermillod-Blondin F, Malard F, Gibert J (2011) Response of sediment biofilm to increased dissolved organic carbon supply in groundwater artificially recharged with stormwater. J Soils Sediments 11:382-393

Fredrickson JK, Garland TR, Hicks RJ, Thomas JM, Li SW, McFadden KM (1989) Lithotrophic and heterotrophic bacteria in deep subsurface sediments and their relation to sediment properties. Geomicrobiol J 7:53-66

Frimmel FH (1992) Isolation and general characterization of organic acids from pore water. In: Matthess $G$, Frimmel FH, Hirsch P, Schulz HD, Usdowski E (eds) Progress in hydrogeochemistry. Springer, Berlin-Heidelberg, p 9-13

Fuhrman JA, Bell TM (1985) Biological considerations in the measurement of free amino acids in seawater and implications for chemical and microbiological studies. Mar Ecol Prog Ser 25:13-21

* Goldman JC, Caron DA, Dennett MR (1987) Regulation of gross growth efficiency and ammonium regeneration in bacteria by substrate $\mathrm{C}: \mathrm{N}$ ratio. Limnol Oceanogr 32: 1239-1252

*Goldscheider N, Hunkeler D, Rossi P (2006) Microbial biocenoses in pristine aquifers and an assessment of investigation methods. Hydrogeol J 14:926-941

Gooddy DC, Hinsby K (2008) Organic quality of groundwater. In: Edmunds WM, Shand P (eds) Natural groundwater quality. Blackwell, Oxford, p 59-70

* Griebler C, Lueders T (2009) Microbial biodiversity in groundwater ecosystems. Freshw Biol 54:649-677

Griebler C, Mindl B, Slezak D, Geiger-Kaiser M (2002) Distribution patterns of attached and suspended bacteria in pristine and contaminated shallow aquifers studied with an in situ sediment exposure microcosm. Aquat Microb Ecol 28:117-129 
Griebler C, Malard F, Lefébure T (2014a) Current developments in groundwater ecology - from biodiversity to ecosystem function and services. Curr Opin Biotechnol 27:159-167

Griebler C, Hahn HJ, Stein H, Kellermann C and others (2014b) Development of biological assessment tools and criteria for groundwater ecosystems. Report of the German Federal Environmental Agency (UBA) UFOPLAN, FKZ 370823 200. UBA, Berlin

Guenet B, Danger M, Abbadie L, Lacroix G (2010) Priming effect: bridging the gap between terrestrial and aquatic ecology. Ecology 91:2850-2861

* Guenet B, Danger M, Harrault L, Allard B and others (2014) Fast mineralization of land-born $\mathrm{C}$ in inland waters: first experimental evidences of aquatic priming effect. Hydrobiologia 721:35-44

*Hammes F, Goldschmidt F, Vital M, Wang Y, Egli T (2010) Measurement and interpretation of microbial adenosine tri-phosphate (ATP) in aquatic environments. Water Res 44:3915-3923

Hertkorn N, Claus H, Schmitt-Kopplin Ph, Perdue EM, Filip Z (2002) Utilization and transformation of aquatic humic substances by autochthonous microorganisms. Environ Sci Technol 36:4334-4345

Hessen DO, Anderson TR (2008) Excess carbon in aquatic organisms and ecosystems: physiological, ecological, and evolutionary implications. Limnol Oceanogr 53: 1685-1696

Jones JB (1995) Factors controlling hyporheic respiration in a desert stream. Freshw Biol 34:91-99

Kalbitz K, Solinger S, Park JH, Michalzik B, Matzner E (2000) Controls on the dynamics of dissolved organic matter in soils: a review. Soil Sci 165:277-304

Keck F, Lepori F (2012) Can we predict nutrient limitation in streams and rivers. Freshw Biol 57:1410-1421

Kieft TL, Phelps TJ (1997) Life in the slow lane: activities of microorganisms in the subsurface. In: Amy PS, Haldeman DL (eds) The microbiology of the terrestrial deep subsurface. Lewis Publishers, Boca Raton, FL, p 137-163

Kinner NE, Harvey RW, Shay DM, Metge DW, Warren A (2002) Field evidence for a protistan role inorganicallycontaminated aquifer. Environ Sci Technol 36:4312-4318

Kirchman DL (1993) Leucine incorporation as a measure of biomass production by heterotrophic bacteria. In: Kemp PF, Sherr BF, Sherr EB, Cole JJ (eds) Handbook of methods in aquatic microbial ecology. Lewis Publishers, Boca Raton, FL, p 359-367

Konopka A (2000) Microbial physiological state at low growth rate in natural and engineered ecosystems. Curr Opin Microbiol 3:244-247

Kuzyakov Y (2010) Priming effects: interactions between living and dead organic matter. Soil Biol Biochem 42: 1363-1371

Lennon JT, Pfaff LE (2005) Source and supply of terrestrial organic matter affects aquatic microbial metabolism. Aquat Microb Ecol 39:107-119

Longnecker K, Da Costa A, Bhatia M, Kujawinski EB (2009) Effect of carbon addition and predation on acetateassimilating bacterial cells in groundwater. FEMS Microbiol Ecol 70:456-470

Malard F, Hervant F (1999) Oxygen supply and the adaptation of animals in groundwater. Freshw Biol 41:1-30

Manzoni S, Taylor P, Richter A, Porporato A, Agren GI (2012) Environmental and stoichiometric controls on microbial carbon-use efficiency in soils. New Phytol 196:79-91
Mermillod-Blondin F, Simon L, Maazouzi C, Foulquier A, Delolme C, Marmonier P (2015) Dynamics of dissolved organic carbon (DOC) through stormwater basins designed for groundwater recharge in urban area: assessment of retention efficiency. Water Res 81:27-37

Middelboe M, Sondergaard M (1993) Bacterioplankton growth yield: seasonal variations and coupling to substrate lability and $\beta$-glucosidase activity. Appl Environ Microbiol 59:3916-3921

* Miettinen IT, Vartiainen T, Martikainen PJ (1997) Phosphorus and bacterial growth in drinking water. Appl Environ Microbiol 63:3242-3245

Mindl B, Griebler C, Wirth N, Starry O (2000) Biodegradability of DOC and metabolic response of heterotrophic bacteria in groundwater. Verh Int Verein Limnol 27: 453-459

Murphy J, Riley JP (1962) A modified single solution method for the determination of phosphate in natural waters. Anal Chim Acta 27:31-36

Nebbioso A, Piccolo A (2013) Molecular characterization of dissolved organic matter (DOM): a critical review. Anal Bioanal Chem 405:109-124

Novarino G, Warren A, Butler H, Lambourne G and others (1997) Protistan communities in aquifers: a review. FEMS Microbiol Rev 20:261-275

*Pabich WJ, Valiela I, Hemond HF (2001) Relationship between DOC concentration and vadose zone thickness and depth below water table in groundwater of Cape Cod, U.S.A. Biogeochemistry 55:247-268

Paerl HP (1977) Factors limiting productivity of freshwater ecosystems. Adv Microb Ecol 6:75-110

*Pedersen K (2000) Exploration of the deep intraterrestrial microbial life: current perspectives. FEMS Microbiol Lett 185:9-16

*Phelps TJ, Murphy EM, Pfiffner SM, White DC (1994) Comparison between geochemical and biological estimates of subsurface microbial activities. Microb Ecol 28: 335-349

* Pretty JL, Hildrew AG, Trimmer M (2006) Nutrient dynamics in relation to surface-subsurface hydrological exchange in a groundwater fed chalk stream. J Hydrol 330:84-100

Pridmore RD, Cooper AB, Hewitt JE (1984) ATP as biomass indicator in eight North Island Lakes, New Zealand. Freshw Biol 14:73-78

Kussell JB, Cook GM (1995) Energetics of bacterial growth: balance of anabolic and catabolic reactions. Microbiol Rev 59:48-62

* Schmidt MWI, Torn MS, Abiven S, Dittmar T and others (2011) Persistence of soil organic matter as an ecosystem property. Nature 478:49-56

* Shen Y, Chapelle FH, Strom EW, Benner R (2015) Origins and bioavailability of dissolved organic matter in groundwater. Biogeochemistry 122:61-78

* Smith EM, Prairie YT (2004) Bacterial metabolism and growth efficiency in lakes. The importance of phosphorus availability. Limnol Oceanogr 49:137-147

* Stoewer MM, Knöller K, Stumpp C (2015) Tracing freshwater nitrate sources in pre-alpine groundwater catchments using environmental tracers. J Hydrol 524: 753-767

Stouthamer AH, Bettenhausser C (1973) Utilization of energy for growth and maintainance in continuous and batch cultures of microorganisms. Biochim Biophys Acta 301:53-70 
Taylor PG, Townsend AR (2010) Stoichiometric control of organic carbon-nitrate relationships from soil to the sea. Nature 464:1178-1181

Teixeira de Mattos MJ, Neijssel OM (1997) Bioenergetic consequences of microbial adaptation to low-nutrient environments. J Biotechnol 59:117-126

Thingstad TF, Krom MD, Mantoura RFC, Flaten GAF and others (2005) Nature of phosphorus limitation in the ultraoligotrophic Eastern Mediterranean. Science 309: 1068-1071

Thurman EM, Malcolm RL (1981) Preparative isolation of aquatic humic substances. Environ Sci Technol 15: 463-466

Vallino JJ, Hopkinson CS, Hobbie JE (1996) Modelling bacterial utilization of dissolved organic matter: optimization replaces Monod growth kinetics. Limnol Oceanogr 41: 1591-1609

van Nugteren P, Moodley L, Brummer GJ, Heip CHR, Herman PMJ, Middelburg JJ (2009) Seafloor ecosystem functioning: the importance of organic matter priming. Mar Biol 156:2277-2287

Editorial responsibility: Karel Šimek, České Budějovice, Czech Republic
Vrede K, Heldal M, Norland S, Bratbak G (2002) Elemental composition $(\mathrm{C}, \mathrm{N}, \mathrm{P})$ and cell volume of exponentially growing and nutrient-limited bacterioplankton. Appl Environ Microbiol 68:2965-2971

Wilhartitz IC, Kirschner AKT, Stadler H, Herndl GJ and others (2009) Heterotrophic prokaryotic production in ultraoligotrophic alpine karst aquifers and ecological implications. FEMS Microbiol Ecol 68:287-299

*Wilson CA, Stevenson LH, Chrzanowski TH (1981) The contribution of bacteria to the total adenosine triphosphate extracted from the microbiota in the water of a saltmarsh creek. J Exp Mar Biol Ecol 50:183-195

Wolf M, Buckau G, Geyer S (2004) Isolation and characterization of new batches of Gohy-573 humic and fulvic acids. In: Buckau G (ed) Humic substances in performance assessment of nuclear waste disposal: actinide and iodine migration in the far-field. Second Technical progress report FZKA-6969. FZKA, Karlsruhe, p 111-124

Zhou Y, Kellermann C, Griebler C (2012) Spatio-temporal patterns of microbial communities in a hydrologically dynamic pristine aquifer. FEMS Microbiol Ecol 81:230-242

Submitted: May 17, 2017; Accepted: November 2, 2017 Proofs received from author(s): January 23, 2018 